\title{
Not All Special Interests Are Created Equal: The Role Of Industry Lobbying On WTO Patterns Of Protection
}

\author{
Lynda D. Vargha (E-mail: lvargha@ @kidmore.edu), Skidmore College, USA
}

\begin{abstract}
This paper examines to what degree increase in bilateral and multilateral trade agreements has opened up liberalization process to the special interests of powerful industries in industrialized nations. A political economy model of endogenous tariff formation is used to compare the effects of industry lobbying on the tariff structure under unilateral and cooperative liberalization. The results of this analysis illustrate that industry special interests do have an effect on the tariff structure when trade policy is determined unilaterally or cooperatively (especially if the industries of major trading partners are not organized into effective lobbies). However, the model also illustrates that as countries pursue the ongoing liberalization of tariff protection, large industries will experience larger tariff reductions than smaller ones. In fact, during the process of ongoing unilateral or cooperative liberalization, the industries most able to maintain high levels of protection are those that are characterized by high displacement costs and are particularly susceptible to harm from imports. The paper concludes that regardless of the liberalization mechanism the organized special interests of large industries will affect the pattern of protection, however, this effect diminishes if a country commits to an ongoing liberalization process. Instead, ongoing multilateral liberalization through the WTO keeps tariff policy open as an avenue for the government objective of minimizing the deadweight loss associated with liberalization and protecting industries particularly susceptible to harm from imports.
\end{abstract}

\section{Introduction}

In the past decade, resistance to the WTO has become more vocal in the U.S. and abroad. While much of the recent debate centers on the expanding role of WTO into areas such as labor standards, environmental standards, enforcement of intellectual property rights and trade in services, there still exists a strong underlying opposition to the major goal of the organization: the cooperative multilateral liberalization of trade of goods among member nations.

A major objection to liberalization through the WTO is that its policies over-represent the goals of industrialized members such as the U.S. and the European Union at the expense of poorer, less developed nations. In particular both economists and non-economists have argued that the WTO is a tool for the governments of developed nations, and the industry special interests that influence their trade policy. For example, Clarke (2003) points out that the prevalence of high tariffs in agriculture and manufactured goods among WTO member nations is a result of lobbing by powerful industry special interests in the United States and the European Union. In contrast, the goods in which developed nations have comparative advantage, such as high tech and capital intensive goods, enjoy low tariffs. As a result, the structure of protection among WTO member nations erodes some of the comparative advantage of poorer countries while serving the special interests of large industrialized nations (Clarke 2003). 
To what degree does increase in bilateral and multilateral trade agreements open up liberalization process to the special interests of powerful industries in industrialized nations? This paper aims to answer this question by positing a political economy model of endogenous tariff formation to compare the effects of industry lobbying on the tariff structure under unilateral and multilateral liberalization. The results of this analysis illustrate that industry special interests have an effect on the tariff structure when trade policy is determined unilaterally or multilaterally (especially if the industries of major trading partners are not organized into effective lobbies). However, the model also illustrates that as countries pursue the ongoing liberalization of tariff protection, large industries will experience larger tariff reductions than smaller ones. In fact, during the process of ongoing unilateral or multilateral liberalization, the industries most able to maintain high levels of protection are those that are characterized by high displacement costs and are particularly susceptible to harm from imports. The paper concludes that regardless of the liberalization mechanism (unilateral or multilateral) the organized special interests of large industries will affect the pattern of protection, however, this effect diminishes if a country commits to an ongoing liberalization process. Instead, ongoing multilateral liberalization keeps tariff policy open as an avenue for the government objective of minimizing the deadweight loss associated with liberalization and protecting industries particularly susceptible to harm from imports.

The paper will proceed as follows. The next section will present a brief literature review, while the following section will present the theoretical model. Finally, theoretical results will be presented and policy implications will be discussed.

\section{Literature Review}

This paper uses a political economy model of endogenous tariff formation to compare the effects of industry lobbying when trade policy is determined unilaterally and multilaterally. The model used is a Grossman and Helpman (1995) two country lobbying model of endogenous tariff formation with the addition of linear costs of production adjustment. The inclusion of production adjustment costs will allow the differentiation between industry lobbying to avoid industry loss in rents and lobbying driven by loss due to displacement costs. While the former illustrates the motives of special interests, the latter illustrates the possible motives of government to shape trade policy to avoid imposing additional deadweight loss on society.

It is important to consider the role of displacement costs (or adjustment costs) in trade policy as the international trade literature provides evidence that these costs play a role in determining the trade policy that results from the lobbying process. Production adjustment costs arise because firms must hire or fire employees when output levels change. These costs include disruptions to production from rearranging workers' assignments, search costs of displaced workers, training costs of new workers on employment (or displaced workers on reemployment), and severance pay. Not only do governments gain by avoiding the deadweight loss associated with these costs, industry special interests concentrate on the costs of production adjustment incurred by capital and labor as is evidenced by lobby testimony in the congressional hearings on trade acts and trade negotiations (Cheh, 1974).

In addition, empirical research gives support to the relationship between the degree to which an industry is successful at resisting liberalization and the cost of adjustment in that industry. For example, Bale (1977) concluded that industries with high adjustment costs received greater exceptions from the across the board tariff cuts in the Kennedy Round. Cheh (1974) estimated that one half of the industry variation in reductions in tariff levels and non tariff barriers in the Kennedy Round were accounted for by adjustment costs. Riedel (1977) found similar results for Germany.

The magnitude and the structure of these costs are well documented in the microeconomic literature. For example, Button (1990) and Cascio (1991) find that the firm costs of adjusting labor demand amount to as much as one year of payroll cost for the average worker. More conservative estimates find that these costs are about 20 percent of annual per-worker payroll costs, which, the authors claim, are still large enough to warrant their consideration in analyzing firm behavior. This model assumes that the structure of these displacement costs are linear, an assumption supported by the empirical literature. 


\section{Theoretical Model}

The model is a two country Grossman and Helpman (1995) model with the addition of displacement costs. Each economy produces goods $\mathrm{Z}$ and $\mathrm{Xi}(\mathrm{i}=1, \ldots \mathrm{n})$, and all goods are produced under constant returns to scale. Good $\mathrm{Z}$ is the numeraire good $(\mathrm{pz}=1)$ and its production uses one unit of labor to produce one unit of output. As a result, the wage rate equals 1 in equilibrium. Goods Xi use both labor and sector specific capital. Since the equilibrium wage rate equals 1 , the return to sector specific capital equals $\Pi i\left(\right.$ pi) where $\mathrm{Xi}(\mathrm{pi})=\Pi \mathrm{i}^{\prime}(\mathrm{pi})$.

Total displacement costs incurred by the owners of capital in industry $i$ are a function of the unit cost of adjustment and magnitude of adjustment in that industry. The adjustment cost function is defined as follows:

$$
\Phi_{\mathrm{i}}\left(\tau_{i} \pi_{i}, \tau_{i}(s q) \pi i(s q)\right)=\kappa_{\mathrm{i}} \mu_{i}>0
$$

where the marginal cost of adjustment is assumed to be positive and constant ( $\kappa \mathrm{i}>0$ ), and the magnitude of adjustment is represented by $\mu \mathrm{i}=|\mathrm{Xi}(\tau \mathrm{i} \pi \mathrm{i})-\mathrm{Xi}(\mathrm{sq})(\tau \mathrm{i}(\mathrm{sq}) \pi \mathrm{i}(\mathrm{sq}))|$ where $\mathrm{Xi}(\mathrm{sq})$ equals status quo output in industry $\mathrm{i}$. The unit cost of adjustment ( $\mathrm{ki}$ ) is restricted to a magnitude small enough to ensure that it erodes the gains from changing to a new level of output but does not eliminate them completely.

Assumptions about the formation of lobbies, the government objective function, and the lobbying process are consistent with the Grossman and Helpman (1995) model. In sector i, individuals endowed with sector specific capital form a lobby. There exists an exogenous set organized industries (L). The government maximizes its objective function that is a weighted average of contributions and aggregate welfare:

$$
\mathrm{G}=\sum_{\mathrm{i} \in L} \mathrm{C}(\tau, \cdot)+\mathrm{a} \mathrm{W}(\tau, \pi)
$$

where $a \geq 0$ is the government's weight on aggregate welfare relative to contributions, and $W(\tau, \pi)$ is aggregate welfare.

From Grossman and Helpman (1995), the non-cooperative equilibrium home policy response to a foreign policy vector satisfies

(3) $\nabla_{\tau} \mathrm{Wi}(\mathbf{p})+\mathrm{a} \nabla_{\tau} \mathrm{W}(\mathbf{p})=0$

With the addition of adjustment costs, the equilibrium tariff vector is:

where ei* $=\tau \mathrm{i}^{*} \pi \mathrm{iMi}^{*}{ }^{\prime} / \mathrm{Mi}^{*}$.

$$
\tau_{\mathrm{i}}-1=\frac{-\mathrm{X}_{\mathrm{i}}+(1+\mathrm{a}) \kappa i\left(\mu \mathrm{i}^{\prime}\right)\left(\mathrm{X}^{\prime} \mathrm{i}\right)}{\mathrm{a} \pi_{\mathrm{i}} \mathrm{Mi}^{\prime}}+\frac{1}{\mathrm{ei} *}
$$

In equation (4), the tariff rate in each industry is expressed as the sum of two expressions. The first expression is the political support effect, which is caused by the government's willingness to impose deadweight loss on its constituents in order to collect contributions. The second expression represents the terms of trade effect, which exists since it is optimal for a country that can affect world prices to impose a tariff to obtain a favorable terms of trade effect.

The political support effect is positive for organized industries and negative for industries without organized lobbies. The terms of trade effect is positive for import competing industries and negative for exporting industries. Therefore, an organized import competing industry emerges from the lobby process with a protective tariff. 
Equation (4) also illustrates the causes of cross industry variation in tariff levels among competing industries. These variations are due to differences in the price sensitivity of import demand (Mi'), industry output $(\mathrm{Xi})$, adjustment costs $(\kappa \mathrm{i})$ and the elasticity of foreign export supply or import demand (ei*). The implications of these results will be discussed in the next section.

Starting from the status quo policy vectors, instead of setting tariffs unilaterally, politicians from both countries can bargain over both home and foreign country trade policy vectors $\tau$ and $\tau^{*}$. In doing so, each government will maximize its objective function:

$$
\mathrm{G}=\sum_{\mathrm{i} \in L} \mathrm{C}(\tau, \cdot)+\mathrm{aW}(\tau, \pi)
$$

and

$$
\mathrm{G}^{*}=\sum_{\mathrm{i} \in L} \mathrm{C}^{*}(\tau, \cdot)+\mathrm{a} * \mathrm{~W} *(\tau, \pi)
$$

The cooperative equilibrium is represented by:

$$
\tau_{\mathrm{i}}-\tau_{\mathrm{i}}^{*}=\frac{-\mathrm{X}_{\mathrm{i}}+(1+\mathrm{a}) \kappa_{i}\left(\mu_{\mathrm{i}}^{\prime}\right)\left(\mathrm{X}_{\mathrm{i}}^{\prime}\right)}{\mathrm{a} \pi_{\mathrm{i}} \mathrm{M}_{\mathrm{i}}^{\prime}}-\frac{-\mathrm{X}_{\mathrm{i}}^{*}+\left(1+\mathrm{a}^{*}\right) \kappa_{i}^{*}\left(\mu_{\mathrm{i}}^{\prime}{ }^{*}\right)\left(\mathrm{X}_{\mathrm{i}}^{* *^{\prime}}\right)}{\mathrm{a} * \pi_{\mathrm{i}} * \mathrm{M}_{\mathrm{i}} *^{\prime}}
$$

Since the functions on the right side of the equation (6) are homogeneous of degree zero in $\tau i$ and $\tau i^{*}$, dividing both sides by $\tau \mathrm{i}^{*}$ yields the ratio $\tau \mathrm{i} / \tau \mathrm{i}^{*}$. This ratio determines international prices in both countries and therefore determines output, demands, trade flows, and returns to sector specific capital in both countries. Which equilibrium vectors of $\tau i$ and $\tau i^{*}$ are chosen will depend on the result of the bargaining process.

In equation (6) the set of efficient equilibria is expressed as the sum of two expressions. The first expression is the political support effect of the home country, and the second expression is the political support effect of the foreign country. Cross industry variation in tariff levels among competing industries are due to differences in the price sensitivity of import demand (Mi', Mi*'), industry output (Xi, $\left.\mathrm{Xi}^{*}\right)$, and adjustment costs $\left(\kappa i, \kappa i^{*}\right)$ in both countries.

\section{Theoretical Results And Policy Implications}

The unilateral equilibrium (equation 4) provides three major results. First, when governments set trade policy unilaterally, large organized import competing industries will receive a higher the level of protection as a result of the lobbying process than small industries. Industries with higher levels of output will gain more protection from lobbying than smaller industries because the specific factor owners in industry $i$ have more to gain from an increase in the domestic price of their good the larger the industry. Therefore the lobbies of large industries will lobby harder to obtain and maintain protection, and patterns of protection will favor large organized industries over small ones.

Second, since the government weighs the deadweight loss of a tariff on social welfare, cross industry tariff levels will favor domestic industry that is more susceptible to harm from import competition. Therefore, the government is more likely to maintain high tariffs in industries that are characterized by large displacement costs (кi). In addition, these industries will lobby more to maintain protection since they share in the deadweight loss. So, while large organized industries do receive high tariff protection as a result of the lobbying process, unilateral trade policy also remains an avenue for countries to help those industries particularly susceptible to harm from liberalization.

Finally, the unilateral equilibrium illustrates that high adjustment cost industries will be better able to maintain protection during an ongoing process of unilateral liberalization than large industries. This result is derived from (4). 


$$
\delta \tau_{i} / \delta \mathrm{a}=\frac{\mathrm{X}_{\mathrm{i}}-\kappa_{i} \mathrm{X}_{\mathrm{i}}^{\prime}}{\mathrm{a}^{2} \pi_{i} \mathrm{M}_{\mathrm{i}}^{\prime}}<0 \quad \text { since } \mathrm{X}_{\mathrm{i}}>\kappa_{i} \mathrm{X}_{\mathrm{i}}^{\prime} \text { and } \mathrm{M}^{\prime}<0
$$

As a government puts more weight on social welfare relative to contributions (a), industry i's import tariff will decline as a result of the change. Large industries will see a larger decline in their tariffs than small ones, however, the larger the marginal cost of adjustment in industry $i$, the less $\tau i$ will decline as a result of an increase in the parameter a. (Note that as $\kappa i$ increases, the numerator becomes smaller causing $\delta \tau i / \delta$ a to become less negative.)

Intuitively, this result stems from the fact that adjustment costs impose a form of deadweight loss on an industry, (the larger the marginal cost of adjustment, the larger the deadweight loss from each unit of output adjustment). Therefore, organized industries will lobby more strongly against any deviation from status quo trade policy and the government will grant a smaller deviation for each level of contribution since it wishes to avoid imposing excessive deadweight loss on its constituents.

The cooperative equilibrium provides two major results. First, when governments set trade policy cooperatively, an organized import competing industry will receive more protection if the same industry in the foreign country is not organized. Second, if both are organized, and if the domestic industry is large relative to foreign industry, net protection will benefit domestic industry. This result is derived from equation (6). If the domestic industry is organized ti-ti* will be smaller if the foreign industry is also organized then if it is not. If domestic is organized and foreign is not, it will keep protection. But, if foreign is organized, relative protection favors larger industry.

It is intuitive that a large organized lobby will do better in bilateral or multilateral negotiations if its foreign competition is not organized. This result also mirrors reality. For example, manufacturing and agricultural industries that are organized in U.S. and European union have maintained higher levels of protection as a result of the ongoing process of WTO (and previously GATT) negotiation than their competitors in less developed nations. The result of this pattern of protection is the erosion of some of the comparative advantage gains from trade for the poorer nations.

Second, the cooperative equilibrium, like the unilateral equilibrium, provides the result that high adjustment cost industries will be better able to maintain protection during an ongoing process of unilateral liberalization than large industries. This result is derived from (6).

$$
\delta\left(\tau_{i}-\tau_{i}^{*}\right) / \delta \mathrm{a}=\frac{\mathrm{X}_{\mathrm{i}}-\kappa_{i} \mathrm{X}_{\mathrm{i}}^{\prime}}{\mathrm{a}^{2} \pi_{i} \mathrm{M}_{\mathrm{i}}{ }^{\prime}}<0 \quad \text { since } \mathrm{X}_{\mathrm{i}}>\kappa_{i} \mathrm{X}_{\mathrm{i}}^{\prime} \text { and } \mathrm{M}_{\mathrm{i}}^{\prime}<0
$$

indicating as the home government places more weight on aggregate welfare relative to contributions, $\tau i$ - $\tau i^{*}$ decreases causing industry i protection to favor the foreign country. Similarly,

$$
\delta\left(\tau_{i}-\tau_{i}^{*}\right) / \delta \mathrm{a} *=-\frac{\mathrm{X}_{\mathrm{i}}^{*}-\kappa_{i} * \mathrm{X}_{\mathrm{i}}^{* \prime}}{\mathrm{a}^{* 2} \pi_{\mathrm{i}} \mathrm{M}_{\mathrm{i}} *^{\prime}}>0 \quad \text { since } \mathrm{X}_{\mathrm{i}} *>\kappa_{i}^{*} \mathrm{X}_{\mathrm{i}}^{* \prime} \text { and } \mathrm{M}_{\mathrm{i}}^{* \prime}<0
$$

indicating as the foreign government places more weight on aggregate welfare relative to contributions, $\tau i$ - $\tau i^{*}$ increases causing industry i protection to favor the home country. Assuming symmetry in all other variables, if $\kappa \mathrm{i}>\mathrm{Ki}^{*}$ then $(7)>\left(7^{*}\right)$ indicating that the new trade policy ratio will favor the home country. If $\kappa \mathrm{i}>\mathrm{\kappa i}^{*}$, then $(7)<\left(7^{*}\right)$ causing the new trade policy ratio to favor the foreign country.

Intuitively, this result comes from the fact that the home government is less willing to change its trade policy since this will impose greater deadweight loss the higher the marginal cost of adjustment. Therefore, the home government is more open to industry i's bids for protection than the foreign government is to industry $i^{*}$ 's. 
The implication of this result is that even in multilateral negotiations, as governments commit to greater levels of liberalization, an industry is more able to hold on to protection the higher its marginal cost of production adjustment. This result is consistent with empirical evidence of GATT negotiated patterns of protection in U.S. manufacturing industries.

Finally, it is important to note that organized industries characterized by high displacement costs will lobby more to avoid the removal of protection in their industry since they share in the deadweight loss. As a result, these industries will lobby more strongly against any deviation from status quo trade policy and the government will grant a smaller deviation for each level of contribution since it wishes to avoid imposing excessive deadweight loss on its constituents. These results imply that cross industry differences in tariff protection is not only the product of a government with a social objective to minimize deadweight loss but the response of a utility maximizing government facing the lobbying of utility maximizing industries. In fact, even if the government did not take into consideration social welfare, the strong lobbying of organized industries that would incur high displacement costs from liberalization would be able to hold on to higher levels of tariff protection.

\section{Conclusion}

This paper illustrates that while governments are susceptible to special interest lobbying, these special interests have an effect on the tariff structure whether trade policy is determined unilaterally or cooperatively. Therefore, while the model does provide evidence in favor of the argument that large powerful industries can be favored by the pattern of protection resulting from GATT and WTO policies, unilateral liberalization will produce a similar result.

It is also important to note that the influence of industry special interests is particularly large during multilateral liberalization when the domestic industry is organized and the foreign is not. This result is consistent with patterns of protection in some agricultural and manufactured products, where the WTO patterns of protection favor industry interests in the United States and European Union at the detriment of these industries in developing countries.

While it is not the fault of the WTO that the tariff structure is susceptible to special interests of organized industries in developing countries, these results highlight the importance of the WTO's role in administering trade policy susceptible to such a result. The WTO must recognize that there is potential for industries in poorer countries to lose some of the gains from their comparative advantage due to the lobbying of special interests in industrialized nations, and it implies a role for the WTO to administer the liberalization process in a way that does not allow liberalization to the detriment of its poorest members.

The paper also provides evidence that cross industry differences in tariff protection occur not just from large industry lobbying, but from the lobbying of industries attempting to avoid high displacement costs (and the governments desire to avoid imposing these costs on society). The model illustrates that whether liberalization is unilateral or multilateral, large industries actually lose more protection than smaller ones (because they have more protection in the first place), and high displacement cost industries are more successful at maintaining protection.

It is promising that multilateral liberalization through the WTO leaves open the avenue for government's to protect declining industry (and for those organized declining industries to effectively lobby for protection). Therefore, as more governments commit to the ongoing liberalization process, it is inaccurate to identify all lobbying activity as the search for rents by politically powerful special interests. Instead, it is important for the WTO to distinguish between industry political interest lobbying and the lobbying to avoid excessive deadweight loss. 


\section{References}

1. Bale, M. D. (1977), "United States Concessions in the Kennedy Round and Short-run Labor Adjustment Costs,"

2. Journal of International Economics, 7, 145-148.

3. Button, Peter (1990), "The Cost of Labour Turnover: An Accounting Perspective," Labour Economics and Productivity, 2(2), 245-73.

4. Cascio, Wayne (1991), Costing Human Resources: The Financial Impact of Behavior in Organizations, PWS-Kent: Boston.

5. Cheh, John H (1974), "United States Concessions in the Kennedy Round and Short-run Adjustment Costs," Journal of International Economics, 4(4), 323-340.

6. Clark, John (2003), Worlds Apart: Civil Society and the Battle for Ethical Globalization, Kumarian Press: Bloomfield.

7. Grossman, Gene and Elhanan Helpman (1995), "Trade Wars and Trade Talks," Journal of Political Economy, 103(4), 675-708.

8. Riedel, James (1977), "Tariff Concessions in the Kennedy Round and the Structure of Protection in West Germany," Journal of International Economics, 7, 133-143.

Notes 
Notes 